\title{
The Danish Supreme Court's Ajos judgment (Dansk Industri): Rejecting a Consistent Interpretation and Challenging the Effect of a General Principle of EU Law in the Danish Legal Order
}

\author{
Sim Haket* \\ PhD Candidate at Utrecht University's Montaigne Centre for Judicial Administration \\ and Conflict Resolution
}

\begin{abstract}
The Danish Supreme Court rejects a consistent interpretation of national law. This outcome is not beyond dispute, but is not clearly in violation with the court's EU law obligations. It also refuses to disapply the incompatible national provision on the basis of the general principle of EU law prohibiting discrimination on grounds of age. Thereby the ECJ's preliminary ruling in the case is disregarded and the Danish Supreme Court's reasoning is problematic from the perspective of EU law.
\end{abstract}

\section{Introduction}

It is by now well-established that directives cannot be invoked against another individual, i.e. in so-called horizontal disputes. ${ }^{1}$ This prohibition of horizontal direct effect has been qualified by the ECJ through the introduction of a number of flanking policies. ${ }^{2}$ The object of this article is to analyse the Danish Supreme Court's approach to two of these flanking policies in the Ajos judgment: the duty of consistent interpretation and the application of the general principle of EU law prohibiting discrimination on grounds of age as a basis for review in horizontal disputes. The former remedy was established in the

* DOI 10.7590/187479817X14945955772000 1874-7981 2017 Review of European Administrative Law

1 Case 152/84 M.H. Marshall v. Southampton and South-West Hampshire Area Health Authority (Teaching), ECLI:EU:C:1986:84, para. 48; Case C-91/92 Paola Faccini Dori v. Recreb Srl, ECLI:EU:C:1994:292, para. 20; Joined Cases C-397 to C-403/o1 Pfeiffer and Others v. Deutsches Rotes Kreuz, Kreisverband Waldshut eV, ECLI:EU:C:2004:584, para. 108.

2 See P. Craig \& G. De Búrca, EU Law (Oxford 2015) 206 for an overview of these judicially crafted flanking policies. 
ECJ's Von Colson and Kamann judgment,' and requires '(...) national courts and administrative authorities to interpret the applicable national law as much as possible in a way which ensures the fulfilment of obligations deriving from European law'. ${ }^{4}$ The second remedy was established in the ECJ's Mangold judgment and refined in the Kücükdeveci judgment. ${ }^{5}$ It states that, if national legislation falls within the scope of EU law, it must be examined to whether it is compatible with EU law which in those two judgments was de facto determined by reference to the Equal Treatment Directive, ${ }^{6}$ and that conclusion was then transferred to the general principle of EU law prohibiting discrimination on grounds of age, which functioned as the de jure basis for review. ${ }^{7}$

This article will proceed as follows. Section 2 describes the facts of the Ajos case, and briefly addresses the ECJ's preliminary ruling, which preceded the Danish Supreme Court's judgment. ${ }^{8}$ The latter judgment's reasoning and decision is described in section 3. Section 4 analyses the Danish Supreme Court's approach to the duty of consistent interpretation and the application of the general principle of EU law prohibiting discrimination on grounds of age in the national proceedings concerning a dispute between two individuals. The analysis focusses on the Danish Supreme Court's approach from the perspective of EU law. While it does not aim to take a position on the judgment's correctness from the perspective of Danish law, it does raise two questions concerning this perspective when discussing the duty of consistent interpretation.

3 Case 14/83 Sabine von Colson and Elisabeth Kamann v. Land Nordrhein-Westfalen, ECLI:EU:C:1984:153. See also Case C-106/89 Marleasing SA v. La Comercial Internacional de Alimentacion SA, ECLI:EU:C:1990:395; Joined Cases C-397 to C-403/o1 Pfeiffer and Others $v$. Deutsches Rotes Kreuz, Kreisverband Waldshut eV, ECLI:EU:C:2004:584.

4 Prechal, 'Direct Effect, Indirect Effect, Supremacy and the Evolving Constitution of the European Union', in: C. Barnard (Ed.), The Fundamentals of EU Law Revisited: Assessing the Impact of the Constitutional Debate (Oxford 2007) 37-38.

5 Case C-144/04 Werner Mangold v. Rüdiger Helm, ECLI:EU:C:2005:709; Case C-555/07 Seda Kücükdeveci v. Swedex GmbH \& Co. KG, ECLI:EU:C:2010:21.

6 Council Directive $2000 / 78 /$ EC of 27 November 2000 establishing a general framework for equal treatment in employment and occupation [2000] OJ L303/16.

7 The distinction between the de facto and de jure legal basis for review can be found in M. De Mol, 'Kücükdeveci: Mangold Revisited - Horizontal Direct Effect of a General Principle of EU Law' (2010/2) ECLR 300.

8 For a more detailed analysis of the ECJ's Ajos judgment see S.W. Haket, 'Dansk Industri: nadere afbakening grenzen aan richtlijnconforme interpretatie en horizontale werking algemeen Unierechtelijk beginsel?’ (2016/7) NtEr 237-242. See also E. Gualco \& L. Lourenço, “'Clash of Titans”. General Principles of EU Law: Balancing and Horizontal Direct Effect' (2016/2) European Papers 643-652; M.J.M. Verhoeven, 'Unierechtelijk verbod op leeftijdsdiscriminatie' (2016/9) SEW Tijdschrift voor Europees en economisch recht 401-403; F. Kainer, 'Privatrecht zwischen Richtlinien und Grundrechten' (2016/6) Zeitschrift für das Privatrecht der Europäischen Union 262-270. 


\section{The Facts of the Ajos Case and the ECJ's Preliminary Ruling}

The legal heirs of Rasmussen brought proceedings against Ajos A/S concerning the latter's refusal to grant a severance allowance equal to three months' salary. The severance allowance aims to assist employees with at least 12 years of service in finding new employment. ${ }^{9}$ According to $\ 2 \mathrm{a}(1)$ funktionorloven (hereinafter: Law on salaried employees) entitlement to a severance allowance equal to three months' salary requires that the employee has been continuously employed in the same undertaking for 18 years before the termination of the employment relationship. Rasmussen wished to find new employment and the conditions stipulated in $\int 2 \mathrm{a}(1)$ were met. However, since Rasmussen could, at the time of the termination of the employment relationship, receive an old-age pension from the employer, it followed from $\mathbb{2} 2 \mathrm{a}(3)$ of the Law on salaried employees, as consistently interpreted in national case law, that no severance allowance was payable. Rasmussen invoked the ECJ's Ole Andersen judgment which provided that $\int 2 \mathrm{a}(3)$ of the Law on salaried employees was incompatible with Article 2 and 6(1) of the Equal Treatment Directive..$^{10}$

In the Ole Andersen judgment the Equal Treatment Directive was relied upon against the state, whereas Rasmussen invoked the provisions of the directive in a horizontal dispute. When the case came before the Danish Supreme Court it decided to make a reference for a preliminary ruling. It observed that, while $\int 2 \mathrm{a}(3)$ of the Law on salaried employees states that no severance allowance is payable if the employee will receive an old-age pension, this has consistently been interpreted to include an employee who could receive the pension at the time of termination of the employment relationship but who temporarily waived his right to that pension and remains on the employment market. The Danish Supreme Court argued that it was therefore impossible to adopt a consistent interpretation. Against this background, the Danish Supreme Court asked the ECJ whether the general principle of EU law prohibiting discrimination on grounds of age can be invoked against a private employer to require him to pay the severance allowance. It thereby raised the question of the effect of this general principle of EU law in a horizontal dispute. It asked in particular whether it is consistent with EU law to weigh the direct effect of the general principle of EU law against the principle of legal certainty and the principle of the protection of legitimate expectations. Finally, it was asked whether it was necessary in this regard to take into consideration the fact that the employee

9 The aim of the severance allowance is stated in para. 26 of the ECJ's Ajos judgment, Case C-441/14 Dansk Industri (DI), acting on behalf of Ajos A/S v. Estate of Karsten Eigil Rasmussen, ECLI:EU:C:2016:278.

10 Case C-499/o8 Ingeniørforeningen i Danmark v. Region Syddanmark, ECLI:EU:C:2010:600, para. 49 . 
may, in appropriate cases, claim compensation from the state for breach of EU law.

In the preliminary ruling the ECJ provided that:

'(...) the source of the general principle prohibiting discrimination on grounds of age (...) is to be found (...) in various international instruments and in the constitutional traditions common to the Member States. It is also apparent from the Court's case-law that that principle, now enshrined in Article 21 of the Charter of Fundamental Rights of the European Union, must be regarded as a general principle of EU law'."

Using the same approach as the one adopted in the Kücükdeveci judgment, the ECJ first held that the Equal Treatment Directive brought the national legislation within the scope of the general principle of EU law prohibiting discrimination on grounds of age (the national provision concerned the conditions regarding dismissal for the purpose of Article 3(1) of the Equal Treatment Directive). ${ }^{12}$ Secondly, referring to the Ole Andersen judgment and using the Equal Treatment Directive as the de facto basis for review, the ECJ recalled the discriminatory nature of $\llbracket 2 \mathrm{a}(3)$ of the Law on salaried employees and concluded that the same applied with regard to '(...) the fundamental principle of equal treatment, the general principle prohibiting discrimination on grounds of age being merely a specific expression of that principle'. ${ }^{13}$ Next, the ECJ addressed the consequences of this conclusion for the national proceedings. It recalled that ' (...) a directive cannot of itself impose obligations on an individual and cannot therefore be relied upon as such against an individual'. ${ }^{14}$ In response to the Danish Supreme Court's observation that a consistent interpretation would be impossible, the ECJ considered it necessary to provide a further delineation of the national courts' discretion when applying the duty of consistent interpretation:

'(...) the requirement to interpret national law in conformity with EU law entails the obligation for national courts to change its established case-law, where necessary, if it is based on an interpretation of national law that is incompatible with the objectives of a directive. Accordingly, the national court cannot validly claim in the main proceedings that it is impossible for it to interpret the national provision at issue in a manner that is consistent with EU law by mere reason of the fact that it has consistently interpreted that provision in a manner

11 Case C-441/14 Dansk Industri (DI), acting on behalf of Ajos A/S v. Estate of Karsten Eigil Rasmussen, ECLI:EU:C:2016:278, para. 22. For the first part of this paragraph the ECJ refers to Case C-144/O4 Werner Mangold v. Rüdiger Helm, ECLI:EU:C:2005:709, para. 74; Case C-555/07 Seda Kücükdeveci v. Swedex GmbH \& Co. KG, ECLI:EU:C:2010:21, paras. 20-21. For the second part it refers to para. 75 of the Mangold judgment and para. 21 of the Kücükdeveci judgment.

2 Ibid, para. 25 .

13 Ibid, para. 26.

14 Ibid, para. 30. 
that is incompatible with EU law'. ${ }^{15}$

After this clarification, the ECJ addressed the question of the effect of the general principle of EU law prohibiting discrimination on grounds of age in a horizontal dispute. Referring to the Kücükdeveci judgment and the need to ensure the full effectiveness of EU law, the ECJ provided that the national court is under an obligation to provide 'the legal protection which individuals derive from EU law (...) disapplying if need be any provision of national legislation contrary to [the general principle of EU law prohibiting discrimination on grounds of age] ${ }^{, 6}$ It held that this obligation was not altered by the principle of legal certainty, the principle of the protection of legitimate expectations, or the possibility to claim compensation from the state for breach of EU law. ${ }^{17}$ To be more precise, the ECJ placed the Danish Supreme Court's invocation of the principle of legal certainty in the broader context of the imperative that an individual should be able to predict the scope of the consequences deriving from a rule of EU law without, however, considering it necessary to take into consideration the specific issues resulting from the nature of the Mangold and Kücükdeveci case law in this regard. ${ }^{18}$

\section{The Danish Supreme Court's Ajos Judgment}

The Danish Supreme Court's reasoning and decision consists of two main parts. In line with the preliminary ruling, it first examined whether it was possible to adopt an interpretation of Danish law that would be consistent with the Equal Treatment Directive, before turning to the possibility to apply the general principle of EU law prohibiting discrimination on grounds of age. It starts out by repeating some of the paragraphs of the ECJ's Ajos judgment concerning the duty of consistent interpretation and its limitations. ${ }^{19}$ It does not, however, repeat the paragraphs in which the ECJ concluded that a consistent interpretation should not be dismissed only because the relevant

15 Ibid, paras. 33-34.

16 Ibid, para. 35. Reference was made to para. 51 of Case C-555/o7 Seda Kücükdeveci v. Swedex GmbH \& Co. KG, ECLI:EU:C:2010:21.

17 Ibid, paras. 38-42.

18 The latter seemed to have been the aim of the Danish Supreme Court. In the judgment making a reference for a preliminary ruling reference was made to the Opinion of AG Trstenjak in Case C-282/10 Maribel Dominguez v. Centre informatique du Centre Ouest Atlantique and Préfet de la région Centre, ECLI:EU:C:2011:559, para. 164, which expresses reservations as regards the compatibility of the ECJ's case law with the principle of legal certainty.

19 Danish Supreme Court case 15/2014 DI, acting on behalf of Ajos A/S v. Estate of A, 42. This article is based on the English translation of the judgment that was made available on the Danish Supreme Court's website: www.supremecourt.dk/supremecourt/nyheder/pressemeddelelser/Documents/Judgment\%2015-2014.pdf. Please note that the authoritative version remains the Danish version. 
provision had been consistently interpreted in a way that is incompatible with EU law. Turning to the relevant provisions in the national proceedings, the Danish Supreme Court mentions a large number of judgments which held that $\int 2 \mathrm{a}(3)$ of the Law on salaried employees should be interpreted so that an employee is not entitled to a severance allowance if he could receive an old-age pension from his employer, irrespective of whether he opted to avail himself of that entitlement. ${ }^{20}$ The Danish Supreme Court refers to a judgment that it delivered in 1991, which had provided that this interpretation followed from the wording of $\int 2 \mathrm{a}(3)$ of the Law on salaried employees, read in conjunction with the travaux préparatoires. ${ }^{21}$ It also refers to an amendment that was made to $\int 2 \mathrm{a}(3)$ of the Law on salaried employees in response to the 1991 judgment, which was designed to prevent employees with very low pension benefits to lose their entitlement to the severance allowance. Otherwise there had not been any amendments material to the interpretation of that provision. ${ }^{22}$ Against this background the Danish Supreme Court concluded that:

'(...) the state of the law is clear and that it is not possible, in applying the rules of interpretation recognised under Danish law, to arrive at an interpretation of Paragraph 2a(3) of the Law on salaried employees as then in force in a manner that is consistent with the Employment Directive as interpreted by the EU Court of Justice in its judgment in [Ole Andersen]. ${ }^{23}$

It should be noted that the Law on salaried employees, including $\mathbb{2} 2 \mathrm{a}(3)$, was not enacted to implement the Equal Treatment Directive. Implementation was effected by the Danish Law prohibiting discrimination on the labour market, which in $\int 1$ provides for a general prohibition of discrimination in employment on the ground of, among others, age. However, the Danish Supreme Court concluded that it was not possible to allow the latter 'to take precedence' over $\int 2 \mathrm{a}(3)$ of the Law on salaried employees to achieve a consistent interpretation. It bases this conclusion on the legislature's assumption that the Equal Treatment Directive did not require that an amendment be made to the Law on salaried employees. ${ }^{24}$ At the end of the first part of the judgment, the Danish Supreme Court concludes that ' $\mathrm{t}$ ] here is thus a contra legem situation (...)', so that a consistent interpretation of $\int 2 \mathrm{a}(3)$ of the Law on salaried employees is not possible. ${ }^{25}$

As regards the second part of the judgment, a majority of eight against one decided that it was impossible to resolve the incompatibility with EU law by applying the general principle of EU law prohibiting discrimination on grounds

Ibid, 43 .

The Danish Supreme Court refers to UfR 1991.317.

Danish Supreme Court case 15/2014 DI, acting on behalf of Ajos A/S v. Estate of A, 43.

Ibid.

24 Ibid. Reference is made to the travaux préparatoires for the Law prohibiting discrimination on the labour market, see Folketingstidende 2004-05, 1. samling, tillæg A, L 92, 2701, point 2.5.

25 Ibid, 44. 
of age. It was provided that, while it is for the ECJ to determine whether EU law has direct effect and takes precedence over conflicting national law (horizontal disputes included), nonetheless:

'[t]he question whether a rule of EU law can be given direct effect in Danish law, as required under EU law, turns first and foremost on the Law on accession by which Denmark acceded to the European Union'. ${ }^{26}$

The Danish Supreme Court subsequently mentions $\llbracket 2$ of that law, which provides for the EU's exercise of the powers which the Constitution conferred on the Danish authorities, '(...) within the limits specified in the treaties, etc., referred to in Paragraph 4 (...)', $\mathbb{\int}$, which gives effect to provisions referred to in Paragraph 4 in the Danish legal order, '(...) in so far as they are directly applicable in Denmark under EU law' and $\mathbb{\int}$, which lists the provisions referred to in $\mathbb{\int} \int$ 2 and 3. The Danish Supreme Court then remarks that the ECJ's Mangold, Kücükdeveci and Ajos judgment do not indicate a specific provision in the Treaties (the TEU and TFEU) providing the basis for 'the principle', so that:

'[a] situation such as this, in which a principle at treaty level under EU law is to have direct effect (thereby creating obligations) and be allowed to take precedence over conflicting Danish law in a dispute between individuals, without the principle having any basis in a specific treaty provision, is not foreseen in the Law on accession'. ${ }^{27}$

It goes on to explain that it was well-known and also foreseen in the Law on accession that the ECJ can develop and establish general principles of EU law. It refers to Article 6(3) TEU, but adds that the view was taken that this provision was not among those covered by $\iint \mathbb{2}$ and 3 of the Law on accession, and was not directly applicable in Denmark. Instead, it was believed that Article 6(3) TEU would only be used to examine whether an EU act breaches rights laid down in the ECHR or in the Member States' constitutions. ${ }^{28}$ The Danish Supreme Court adds that, since the provisions of the Charter, including Article 21 prohibiting discrimination on grounds of age, were not made directly applicable under the Law on accession, it is also not possible to disapply $\mathbb{\int 2 a ( 3 )}$ of the Law on salaried employees on that ground. ${ }^{29}$ Finally, the Danish Supreme Court considers that it '(...) would be acting outside the scope of its powers as a judicial authority if it were to disapply the provision in this situation'.$^{30}$

\footnotetext{
26 Ibid, 45 .

27 Ibid.

28 Ibid, 46.

29 Ibid, 47.

30 Ibid, 48.
} 


\section{Analysis}

\subsection{The Duty of Consistent Interpretation}

The main question that must be answered in this subsection is whether the Danish Supreme Court respects the limits that the ECJ case law imposes in relation to the national courts' discretion when applying the duty of consistent interpretation.

It is remarkable that the Danish Supreme Court repeats the relevant paragraphs of the ECJ's Ajos judgment describing the duty of consistent interpretation and its limitations, but does not mention the part of the ECJ's judgment that seemed to have been the most important: it is not possible to reject a consistent interpretation only because the relevant provision had been consistently interpreted in a way that is incompatible with EU law. ${ }^{31}$ However, looking at the judgment, it cannot be said that the Danish Supreme Court rejected a consistent interpreted on this ground only. It mentions two arguments in support of the interpretation of $\llbracket 2 \mathrm{a}(3)$ of the Law on salaried employees that employees are not entitled to the severance allowance if they could receive an old-age pension from their employer: the wording of that provision, read in conjunction with the relevant travaux préparatoires. While the judgment making a reference for a preliminary ruling could be interpreted as arguing that a consistent interpretation should be rejected by mere reason of contrasting national case law, it is hardly surprising that this case law was actually based on interpretative arguments - which were this time mentioned by the Danish Supreme Court.

Be that as it may, this is not in itself sufficient to answer the question whether the Danish Supreme Court adhered to its obligations under the duty of consistent interpretation. It is submitted that the Danish Supreme Court's argumentation is very thin. For example, it is not explained why the wording of $\int 2 \mathrm{a}(3)$ of the Law on salaried employees prescribes the interpretation adopted by the court (or why it is not open to other interpretations), what part of the travaux préparatoires militates against a consistent interpretation, or how to balance any arguments against and in favour of a consistent interpretation against each other. The duty of consistent interpretation has been interpreted by Jans, Prechal and Widdershoven as requiring the national court '(...) to do its utmost when interpreting national law to reflect, as far as possible, the substance of the directive in question'. ${ }^{2}$ Wissink has interpreted the duty of consistent interpretation as requiring that ' (...) the court should not approach harmonious interpretation as a two staged-exercise, that is first interpreting national

31 This clarification was confirmed in the context of a case concerning a framework decision in Case C-554/14, Criminal proceedings against Ognyanov, ECLI:EU:C:2016:835, paras. 67-69.

32 J.H. Jans, S. Prechal \& R.J.G.M. Widdershoven, Europeanisation of Public Law (Groningen 2015) 75 . 
law in the traditional way and after that comparing the outcome (...) with the requirements of the directive'. ${ }^{33}$ It is questionable whether the Danish Supreme Court's approach meets these expectations.

The above criticism notwithstanding, it remains difficult to determine in abstracto what 'as far as possible' requires, and when an interpretation is contra legem. ${ }^{34}$ The ECJ has generally left it to national courts to decide this, ${ }^{35}$ which only makes sense considering that this is ultimately a question of the national court's discretion under national law and methods of interpretation. Although the judgment's reasoning is very thin, it concerns the interpretation of Danish law, in which regard the Danish Supreme Court is the ultimate authority. ${ }^{36}$ Since it concluded that, on account of the wording of $\int 2 \mathrm{a}(3)$ of the Law on salaried employees and the travaux préparatoires, a consistent interpretation was impossible, it seems difficult to argue, from the perspective of EU law, that this is clearly in breach of the court's obligations under the duty of consistent interpretation. Nonetheless, the question remains whether a consistent interpretation was really impossible on the basis of Danish law. I would therefore like to raise the following two questions, which are intended to spark further discussion:

1. On which grounds, if any, does Danish law preclude the possibility of a consistent interpretation, taking into account that the wording of $\int 2 \mathrm{a}(3)$ of the Law on salaried employees does not seem to preclude - but is rather in favour of - a consistent interpretation, ${ }^{37}$ and the same appears to apply in respect of the travaux préparatoires? ${ }^{38}$ Also, the Danish government

33 Wissink, 'Interpretation of Private Law in Conformity with EU Directives', in: A.S. Hartkamp and others (Ed.), The Influence of EU Law on National Private Law (Deventer 2014) 145.

34 M.H. Wissink, Richtlijnconforme interpretatie van burgerlijk recht (Deventer 2001) 93; J.H. Jans, S. Prechal and R.J.G.M. Widdershoven, Europeanisation of Public Law (Groningen 2015) 80 .

35 P. Craig \& G. De Búrca, EU Law (Oxford 2015) 213.

${ }_{3} 6$ See para. 103 of Case C-212/o4 Konstantinos Adeneler and Others v. Ellinikos Organismos Galaktos (ELOG), ECLI:EU:C:2006:443: '[i]t is not for the Court to rule on the interpretation of domestic law, since that task falls exclusively to the referring court (...)'.

37 Opinion of AG Kokott in Case C-499/08 Ingeniørforeningen i Danmark v. Region Syddanmark, ECLI:EU:C:2010:248, para. 84; Opinion of AG Bot in Case C-441/14 Dansk Industri (DI), acting on behalf of Ajos A/S v. Estate of Karsten Eigil Rasmussen, ECLI:EU:C:2015:776, in particular para. 66.

38 Excerpts of the travaux préparatoires for both the 1971 and 1996 versions of the Law on salaried employees can be found in Danish Supreme Court case 15/2014 DI, acting on behalf of Ajos A/S v. Estate of A, 15-16. Importantly, the travaux préparatoires for the 1971 version provided that the entitlement to the severance allowance is excluded '(...) if the employee will receive a State retirement pension or employer pension (...), that is to say, in situations which usually mean that the person concerned retires from the labour market'. However, according to the facts of the case, Rasmussen had not availed himself of the possibility to receive the pension from his employer so that the situation in which the legislature presumes that workers usually retire does not occur. 
seemed to take the view that a consistent interpretation of $\int 2 a(3)$ of the Law on salaried employees is not excluded. ${ }^{39}$

2. Does it follow from point 5.2 of the travaux préparatoires attached to the Law prohibiting discrimination (to which the Danish Supreme Court referred) that there was an impossibility to adopt an interpretation that limited the scope of $\int 2 \mathrm{a}(3)$ of the Law on salaried employees in a way to avoid conflict with $\int 1$ of the Law prohibiting discrimination on the labour market? To my understanding, point 5.2 primarily concerns the question whether $\int 2 \mathrm{a}$ of the Law on salaried employees constituted indirect discrimination against younger workers. In any event it does not address the specific question of whether the exclusion provided in $\int 2 \mathrm{a}(3)$ is compatible with the Equal Treatment Directive. ${ }^{40}$

\subsection{The Application of the Principle of EU Law Prohibiting Discrimination on Grounds of Age in the National Proceedings}

The paradox of the Danish Supreme Court's conclusion that it could not apply the general principle of EU law prohibiting discrimination on grounds of age is that its reasoning is situated both outside and within the framework of EU law. It provided that: ' $t$ t] he question whether a rule of EU law can be given direct effect in Danish law, turns first and foremost on the Law on accession by which Denmark acceded to the European Union'. ${ }^{41}$ However, the pivot of the Danish Supreme Court's argument is that it could not apply the general principle of EU law prohibiting discrimination on grounds of age because there is not a basis in the Treaties for this general principle of EU law specifically. ${ }^{42}$ I will first explain why the Danish Supreme Court's reasoning must be rejected (subsection 4.2.1) and then examine whether there are more convincing reasons to question that EU law provides a basis for a general

Opinion of AG Bot in Case C-441/14 Dansk Industri (DI), acting on behalf of Ajos A/S v. Estate of Karsten Eigil Rasmussen, ECLI:EU:C:2015:776, para. 63.

Folketingstidende 2004-05, 1. samling, tillæg A, L 92, 2701, point 2.5.

Danish Supreme Court case 15/2014 DI, acting on behalf of Ajos A/S v. Estate of A, 45 .

This follows from the following sentences in the Ajos judgment: ' $t$ the EU Court of Justice does not refer to provisions in those treaties covered by the Law on accession as a basis for the principle' and ' $[\mathrm{t}]$ here is nothing in those judgments, however, to indicate that there is a specific treaty provision providing the basis for the principle', ibid. The consistency with which reference is made to 'the general principle of EU law prohibiting discrimination on grounds of age' or, sometimes, 'the principle', indicates that the court's reasoning concerning the absence of a basis in the Treaties requires the identification of a basis for this specific general principle of EU law, and not general principles of EU law as such. See also E. Gualco, "Clash of Titans 2.0". From Conflicting EU General Principles to Conflicting Jurisdictional Authorities: The Court of Justice and the Danish Supreme Court in the Dansk Industri Case' (2017/1) European Papers 3 . 
principle of EU law prohibiting discrimination on grounds of age (subsection 4.2.2). Finally, the Danish Supreme Court's reasoning in respect of Article 21 of the Charter is briefly addressed (subsection 4.2.3).

\subsubsection{Article 6(3) TEU as a Confirmation of the Dynamic Process of Designating General Principles of EU Law}

A first argument against the Danish Supreme Court's reasoning could be that the operation of a general principle of EU law is not contingent on a basis in the Treaties. This appeals to a widely shared view that general principles of law exist without necessarily having a basis in written legal sources, and also continue to exist when they have been codified. ${ }^{43}$ Although there are, for example, provisions in the Treaties prohibiting discrimination, it is established case law that those provisions are merely specific illustrations of the general principle of EU law prohibiting discrimination which underlies the EU legal order. ${ }^{44}$ It should also be recalled that the ECJ initially developed the general principles of EU law out of necessity to fill the gaps left by written law. ${ }^{45}$ Before the Maastricht Treaty entered into force, there were no written rules which governed this exercise. This did not prevent the ECJ from establishing general principles of EU law on the basis of international treaties for the protection of human rights, in particular the ECHR, and the constitutional traditions common to the Member States. This first argument is unproblematic if the EU legal order is conceived as an autonomous legal order, with the ECJ determining which activities are governed by EU law and which laws are to apply to these activities. However, most national courts do not unconditionally accept this view. ${ }^{46}$ If the first argument was the only argument against the Danish Supreme Court's reasoning, the discussion whether there is an obligation in EU law for national courts to apply general principles of EU law could easily get bogged down in a repetition of arguments concerning the question of the supremacy and autonomy of the EU legal order.

A second argument could be that Article 6(3) TEU (ex Article 6(2) TEU) as such provides the basis for general principles of EU law (including the general principle of EU law prohibiting discrimination on grounds of age). That provision describes the ECJ's method for establishing general principles of EU law. However, it was not directly referred to in the Mangold, Kücükdeveci and Ajos

43 T. Tridimas, General Principles of EU Law (Oxford 2007) 1; Bengoetxea, 'General Legal Principles Navigating Space and Time’, in: U. Bernitz, X. Groussot \& F. Schulyok (Ed.), General Principles of EU Law and European Private Law (Alphen aan den Rijn 2013) 47, 49.

44 Joined Cases 117/76 and 16/77 Albert Ruckdeschel a Co. and Hansa-Lagerhaus Ströh \& Co. v. Hauptzollamt Hamburg-St. Annen; Diamalt AG v. Hauptzollamt Itzehoe, ECLI:EU:C:1977:16o, para. 7 .

45 T. Tridimas, General Principles of EU Law (Oxford 2007) 4.

46 P. Craig \& G. De Búrca, EU Law (Oxford 2015) 266. 
judgments. Also, this argument is difficult to reconcile with the ECJ's use of general principles of EU law before the Maastricht Treaty entered into force. From the perspective of EU law it would therefore not be consistent to see this provision as a prerequisite for the existence of general principles of EU law.

The best counter-argument is in my opinion a compromise between the first and second argument. This contends that the Danish Supreme Court's position does not sufficiently take into account the fact that the Maastricht Treaty, by introducing what is now Article 6(3) TEU, consolidated and reaffirmed the ECJ's practice. It is clear that that process remains a creative and flexible one. The necessity for this approach has been explained by AG Trstenjak:

'(...) the EU legal order is a developing legal order which inevitably has gaps and requires interpretation on account of its openness in respect of integrational development. On the basis of such recognition the Court also appears to have opted not to undertake a precise classification of general principles in order to retain the flexibility it needs in order to decide on substantive matters which arise regardless of terminological discrepancies' ${ }^{47}$

It follows from the above that it is incompatible with the process of designating general principles of EU law, which has been reaffirmed in Article 6(3) TEU, to require a specific provision in the Treaties providing the basis for the general principle of EU law prohibiting discrimination on grounds of age. That provision would become a dead letter if the Danish Supreme Court's reasoning were to be followed. In principle, this suffices to conclude that the Danish Supreme Court's approach is incompatible with EU law. This conclusion is not changed by the court's remark that when Article 6(3) TEU was enacted, the view was taken that that provision was not directly applicable and would only be used to examine whether an EU act is in breach of the sources mentioned in Article 6(3) TEU. First of all, this view does not seem to be consistent with the conclusion that the operation of general principles of EU law is in no way supported by the Treaties. Secondly, by the time that the Maastricht Treaty was adopted it was well-established that general principles of EU law could also be invoked against Member States. ${ }^{48}$ In other words, it was clear that general principles of EU law could also produce effect in the national legal orders and the limited function put forward by the Danish Supreme Court was already out of date at the time of the adoption of the Maastricht Treaty.

Opinion of AG Trstenjak in Case C-282/10 Maribel Dominguez v. Centre informatique du Centre Ouest Atlantique and Préfet de la région Centre, ECLI:EU:C:2011:559, para. 93.

48 See Opinion of AG Sharpston in Case C-427/06 Birgit Bartsch v. Bosch und Siemens Hausgeräte (BSH) Altersfürsorge $\mathrm{GmbH}$, ECLI:EU:C:2008:297, para. 79, with references to case law and observing that this possibility is 'trite' Community law. 


\subsubsection{The Existence of a General Principle of EU Law Prohibiting Discrimination on Grounds of Age}

However, for reasons not mentioned in the Ajos judgment it is not beyond doubt that - in a situation such as the national proceedings in the Ajos case - EU law provides a basis for the general principle of EU law prohibiting discrimination on grounds of age. The ECJ's Mangold judgment based this general principle of EU law only on the sources mentioned in Article 6(3) TEU. This attracted widespread criticism, also by advocates general, providing that while there is support in those sources for a principle of equal treatment, only the Finnish and Portuguese constitutions recognise the principle prohibiting discrimination on grounds of age, and it is not found in any of the international instruments either. ${ }^{49}$ In addition to the sources mentioned in the Mangold judgment, the ECJ's Kücükdeveci and Ajos judgments referred to Article 21 of the Charter. The obligation to disapply conflicting national law was not however based on Article 21 of the Charter but on the general principle of EU law. ${ }^{50}$ This is unsurprising as in both cases the relevant facts took place before the entry into force of the Lisbon Treaty, which conferred binding effect upon the Charter. Nonetheless, one might argue that, at least from the moment that the Charter acquired binding effect, it could be used as a source of inspiration for the establishment of general principles of EU law, even though the facts of a case predated this acquisition..$^{51}$ At first sight, this alternative explanation seems more persuasive: it can be argued that the Charter consolidated a preexisting pan-European consensus concerning fundamental principles and its

49 Opinion of AG Geelhoed in Case C-13/05 Sonia Chacón Navas v. Eurest Colectividades SA, ECLI:EU:C:2006:184, paras. 53-54; Opinion of AG Mazák in Case C-411/o5 Félix Palacios de la Villa v. Cortefiel Servicios SA, ECLI:EU:C:2007:106, paras. 88-97. See also J.H. Jans, 'The Effect in National Legal Systems of the Prohibition of Discrimination on Grounds of Age as a General Principle of Community Law' (2007/1) LIEI 65; Dougan, 'In Defence of Mangold?', in:

A. Arnull and others (Ed.), A Constitutional Order of States? (Oxford 2011) 221; Tridimas, 'Horizontal Effect of General Principles: Bold Rulings and Fine Distinctions', in: U. Bernitz,

X. Groussot \& F. Schulyok (Ed.), General Principles of EU Law and European Private Law (Alphen aan den Rijn 2013) 217.

50 This is apparent from para. 35 and the operative part of Case C-441/14 Dansk Industri (DI), acting on behalf of Ajos A/S v. Estate of Karsten Eigil Rasmussen, ECLI:EU:C:2016:278 and para. 51 and the operative part of Case C-555/o7 Seda Kücükdeveci v. Swedex GmbH Q $\mathrm{Co}$. KG, ECLI:EU:C:2010:21.

51 This view finds support in the Opinion of AG Trstenjak in Case C-282/10 Maribel Dominguez v. Centre informatique du Centre Ouest Atlantique and Préfet de la région Centre,

ECLI:EU:C:2011:559, paras. 72-74; Opinion of AG Kokott in Case C-17/10 Toshiba Corporation and Others v. Úřad pro ochranu hospodářské soutěže, ECLI:EU:C:2011:552, para. 108; K. Lenaerts \& J.A. Gutiérrez-Fons, 'The Constitutional Allocation of Powers and General Principles of EU Law' (2010/6) CMLRev 1655-1656; Dougan, 'In Defence of Mangold?', in: A. Arnull and others (Ed.), A Constitutional Order of States? (Oxford 2011) 223-224. 
use signals judicial deference to the political process. ${ }^{52}$ Yet, this explanation is not entirely unproblematic. Leaving aside the fact that the Charter is not mentioned among the sources in Article 6(3) TEU, a more fundamental concern is that it overlooks that an entirely new general principle of EU law was created. As I just explained, it cannot be said that, with regard to the general principle of EU law prohibiting discrimination on grounds of age specifically, this principle was already enshrined in many legal instruments and is merely codified by the Charter. So indeed, while it may not be problematic to use the Charter as a reference point for well-established general principles of EU law, it is an entirely different matter where it is used as the only basis to establish a general principle of EU law and apply it to a case whose facts predated the Lisbon Treaty. As Iglesias Sánchez explains, when the Charter is the decisive instrument: '[d]isregard of temporal limitations would run counter to the imperatives of the principles of legality and legal certainty, unless we consider that the Charter has not significantly changed the previous legal framework'. ${ }^{53}$

On balance, it seems that although the Danish Supreme Court's reasoning was incorrect, there are more persuasive reasons indicating that the Treaties do not provide a stable basis for the establishment of the general principle of EU law prohibiting discrimination on grounds of age in cases in which the facts predated the entry into force of the Lisbon Treaty. It should be observed that there have been other suggestions to justify a satisfactory basis for this general principle of EU law in particular. ${ }^{54}$ Also, more generally, it has been suggested that Article 19(1) TEU (ex Article 220(1) TEC) stipulates the obligation to apply general principles of EU law. ${ }^{55}$ It is beyond the scope of this article to consider them all in detail here, suffice it to say that, for the purpose of providing a compelling legal basis for application of the general principle of EU law prohibiting discrimination on grounds of age by a national court, they do not offer a more convincing justification than what has just been discussed (i.e. the use of the Charter as a source of inspiration)..$^{56}$ Nonetheless, this issue should now

52 K. Lenaerts \& J.A. Gutiérrez-Fons, 'The Constitutional Allocation of Powers and General Principles of EU Law' (2010/6) CMLRev 1656.

53 S. Iglesias Sánchez, 'The Court and the Charter: The Impact of the Entry into Force of the Lisbon Treaty on the ECJ's Approach to Fundamental Rights' (2012/5) CMLRev 1575.

54 For instance, it was suggested that a more convincing basis is provided by Article 21 of the Charter together with what is now Article 19 TFEU, Opinion of AG Bot in Case C-555/07 Seda Kücükdeveci v. Swedex GmbH \& Co. KG, ECLI:EU:C:2009:429, para. 77. Another example argues that significant support among the national constitutional traditions is not required, as long as the principle resonates with the specific aims and values of the EU itself, see Opinion of AG Kokott in Case C-550/07 Akzo Nobel Chemicals Ltd and Akcros Chemicals Ltd v. European Commission, ECLI:EU:C:2010:229, para. 94.

55 J.H. Jans, S. Prechal \& R.J.G.M. Widdershoven, Europeanisation of Public Law (Groningen 2015) 136-137.

${ }_{56}$ As regards Article 19(1) TEU, this provision states that: '[the ECJ] shall ensure that in the interpretation and application of the Treaties the law is observed'. It is thus directed towards the ECJ and it does not appear implausible to attribute to it a function for the application of general principles of EU law by the ECJ. However, as it is not directed towards national courts and does not indicate which general principles of EU law are to be recognised, it does not seem to 
largely be of historical interest as this category of cases will dry up as time passes and Article 21 of the Charter now provides a clear legal basis and is likely to become the point of reference in primary law in age discrimination cases. ${ }^{57}$ Unfortunately the Danish Supreme Court's judgment contains strong indications that the tensions that surfaced in the Ajos judgment will not simply fade away under the Charter.

\subsubsection{Some Brief Reflections on Article 21 of the Charter}

The Danish Supreme Court held that the provisions of the Charter, including Article 21, are not directly applicable in Denmark under the Law on accession. In the preceding paragraphs the Danish Supreme Court primarily refers to Articles 6(1) TEU and 51 of the Charter, and points out that the Charter is not to alter the competences of the EU. I am not sure to what extent the court's concerns must be viewed in the light of the horizontal nature of the dispute..$^{8}$ However, it does not raise any arguments specifically directed against the horizontal application of Article 21 of the Charter and it can definitely be interpreted as precluding the invocation of provisions of the Charter not merely in horizontal disputes (the same applies, by the way, in respect of the court's considerations regarding the general principle of EU law prohibiting discrimination on grounds of age). It should perhaps be recalled that the dismissal that gave rise to the proceedings in the Ajos case occurred on 25 May 2009, whereas the Lisbon Treaty entered into force on 1 December 2009. Perhaps this influenced the approach of the Danish Supreme Court. Further case law is needed to elucidate the scope and consequences of the considerations in the Ajos judgment concerning the Charter.

be capable of providing a more satisfactory solution for the specific issues occurring in the Ajos case.

57 cf Opinion of AG Cruz Villalón in Case C-447/og Reinhard Prigge and Others v. Deutsche Lufthansa AG, ECLI:EU:C:2011:321, para. 26. In Case C-432/14 O v. Bio Philippe Auguste SARL, ECLI:EU:C:2015:643, a case in which the fact took place after the entry into force of the Lisbon Treaty, the ECJ, although coming to the conclusion that there had been no discrimination on grounds of age, also relied on Article 21 of the Charter in the operative part of the judgment.

58 Discussing this part of the Danish Supreme Court's judgment, Gualco mentions that there is an ongoing debate concerning the horizontal application of the Charter, but she also remarks that the answer to this issue should be provided by the ECJ, and not by a national court, E. Gualco, “"Clash of Titans 2.0”. From Conflicting EU General Principles to Conflicting Jurisdictional Authorities: The Court of Justice and the Danish Supreme Court in the Dansk Industri Case' (2017/1) European Papers 6. 


\section{Conclusion}

In response to a judgment by the Danish Supreme Court concerning the constitutionality of Denmark's ratification of the Lisbon Treaty, Palmer Olsen commented that it appeared to take a tougher stance to ultra vires review of EU acts and ECJ judgments, but nonetheless concluded that:

'[i]t is very doubtful (...) that the Danish Supreme Court would put itself at the centre of European attention by ruling against the ECJ (...). ${ }^{5} .9$

It now turns out that this prediction was too optimistic.

This is not necessarily a result of the Danish Supreme Court rejecting a consistent interpretation. The ECJ has generally left it to the national courts to decide whether a consistent interpretation can be adopted and - save for manifest violations - it is difficult to determine in abstracto whether a national court has failed to interpret national law 'as far as possible'. Nonetheless, it was observed that the judgment's reasoning is very thin and I have raised two questions concerning the alleged impossibility to adopt a consistent interpretation, when considered from the perspective of Danish law. I hope that this will spark further discussion on this part of the Ajos judgment.

From the perspective of EU law, the more problematic part of the judgment concerns the Danish Supreme Court's conclusion that it is not possible to apply the general principle of EU law prohibiting discrimination on grounds of age as a basis for review in the national proceedings. The same conclusion applied in respect of Article 21 of the Charter prohibiting discrimination on grounds of age. In both cases this resulted from the fact that, under the Law on accession, they had not been made directly applicable in Denmark. In the analysis I focussed on the approach to the general principle of EU law prohibiting discrimination on grounds of age which, following the ECJ's Mangold and Kücükdeveci judgments, also applies as a basis for review of national law in a horizontal dispute, such as the national proceedings in the Ajos case. To be sure, those judgments have been criticised, ${ }^{60}$ and it is not beyond doubt that it is possible to derive this specific general principle of EU law from the sources mentioned in Article 6(3) TEU. One way of looking at the Ajos judgment is that it is the result of a court, not being familiar with a tradition of judicial review, ${ }^{61}$ being

59 H. Palmer Olsen, 'The Danish Supreme Court's Decision on the Constitutionality of Denmark's Ratification of the Lisbon Treaty' (2013/5) CMLRev 1503.

6o For an extensive overview of critique on those judgments, from both academics and advocates general, see M. De Mol, 'De horizontale directe werking van de grondrechten van de Europese Unie' (2016/11) SEW Tijdschrift voor Europees en economisch recht 459.

61 While the judgment does not mention this issue it has been observed that, in light of Danish legal culture, in which the Supreme Court's role in the constitutional framework is constricted and where Parliament is dominant, the Ajos case confronted the Danish Supreme Court with a dilemma if it was required to disapply the national law, M. Rask Madsen, H. Palmer Olsen and U. Sadl, 'Competing Supremacies and Conflicting Institutional Rationalities: The Danish Supreme Court's Decision in the Ajos Case and the National Limits of Judicial Cooperation', 2017/85 iCourts Working Paper Series http://papers.ssrn.com/sol3/papers.cfm?abstract_id= 
confronted with this part of the ECJ's case law. However, even against this background, the specific arguments advanced by the Danish Supreme Court do not convince. The first and foremost argument was that the Danish Law on accession does not provide the legal basis to allow the general principle of EU law to take precedence over the conflicting provision of Danish law since the Treaties do not offer a basis for this general principle of EU law specifically. This conclusion does not sufficiently take into account the process of establishing general principles of EU law that has been adopted by the ECJ for a long time and was consolidated and reaffirmed by what is now Article 6(3) TEU. In addition, the Danish Supreme Court argued that, when Article 6(3) TEU was enacted through the Maastricht Treaty, the view was taken that that provision was not directly applicable and would merely be used to examine whether an EU act is in breach of the sources mentioned in Article 6(3) TEU. This view is not entirely consistent with the first argument, and the limited role that it attributes to general principles of EU law is incompatible with their use before the entry into force of the Maastricht Treaty. Perhaps the Danish Supreme Court only intended to reject the possibility of a general principle of EU law being invoked against another individual, which would make sense taking into account the horizontal nature of the national proceedings. Nonetheless, the judgment's reasoning does not necessarily point in that direction and could also be interpreted as potentially covering the effect of general principles of EU law (as well as the Charter) in a broader sense. If it does, the Danish Supreme Court is likely to remain the centre of European attention for some time.

2904012 accessed 1 May 2017. The absence of a tradition of judicial review and the Danish courts' self-restrained approach is mentioned in Due, 'Danish Law in a European Context', in: B. Dahl and others (Ed.), Danish Law in a European Perspective (Copenhagen 1996) 20; J. Elo Rytter and M. Wind, 'In Need of Juristocracy? The Silence of Denmark in the Development of European Legal Norms' (2011/2) ICON 470. 